\title{
BEYOND ANDREWS: Substantive Equality and Positive OBLIGATIONS AFTER ELDRIDGE AND VRIEND
}

\author{
Bruce Porter
}

Reflecting on the first year of equality jurisprudence from the Supreme Court of Canada after the release of the Andrews decision, ${ }^{1}$ Helena Orten, Litigation Director of the Women's Legal Education and Action Fund (LEAF), wrote in 1990 of the new relationship between law and policy, the courts and the legislators. A new relationship had dawned with the Court's recognition that "disadvantag ed groups must be the beneficiaries of positive action on the part of government and others": ${ }^{2}$

The Supreme Court of Canada's approach to

the constitutional right to equality, because it is based on remedying disadvantage rather than treating likes alike, means that laws that have not benefited disadvantaged groups must now do so. The justice system must provide adequate protection against sexual assault and racial violence, women must not be disadvantaged by their reproductive capacity, society must be reorganized to allow full participation of disabled people, even though the advantaged have little or no comparable experience that engages the law.

It is to state the obvious to say that this purposive approach to equality will not be socially or economically neutral. It will also contribute to the change in the customary relationship between the courts and the governm ent. Although many of these changes are considered controversial, what we have seen over the last year is the development of a theoretical and jurisdictional framework that has the potential to be used to achieve the constitutional goal of equality as it was intended by its framers.

Andrews v. Law Society of B ritish Columbia, [1989] 1 S.C.R. 143 (hereinafter Andrews).

H. Orten, "Section 15, Benefits Programs and Other Benef its at Law" (1990) 19 Manitoba Law Journal 288 at 302 .
The theoretical and jurisdictional framework developed in Andrews, however, did not produce the new relationship between rights and politics that equality seekers hoped for. When Helena died last year of cancer, the courts had yet to recognize any general "positive duty" of governments under section 15 to take action to remedy disadvantage and inequality. Before she died, she expressed the hope that the Court would make a long aw aited breakthrough in th is direction in two cases which appeared to raise squarely the issue of positive measures required by section $15-$ Eldridge v. British Columbia (Attorney General) ${ }^{3}$ and Vriend v. Alberta. ${ }^{4}$

In Eldridge, the issue was whether the province of British Columbia violated section 15 by failing to provide interpreter services for the deaf in the provision of health care. In Vriend, the issue was whether the province of Alberta violated section 15 by failing to protect gays and lesbians from discrimination because of sexual orientation. In both cases the Court of Appeal decisions had rejected out of hand the notion that section 15 creates "positive duties" on governments either to provide benefits or to legislate necessary protections for disadvantaged groups. ${ }^{5}$

One is reminded, on reading these two decisions of the Supreme Court, of how tempered has our Charter optimism become since the beginning of this decade. In both decisions the Court harkens back to a time of greater consensus about the Charter and the role of the courts in standing up for the interests of vulnerable minorities.

(1997) 151 D.L.R. (4th) 577 (S.C.C.) (hereinafter Eldridge).

[1998] S.C .J. No. 29 (hereina fter Vriend).

Eldridge v. British Columbia (Attorney General) 125

D.L.R. (4th) 323 (B.C.C.A .) at 341; Vriend v. Alberta 132

D.L.R. (4th) 595 (Alta. C.A.) at 604. 
In Vriend, Cory J., writing for the majority on section 15, invokes without attribution Trudeau's ideal of a "just society." Equality, he says, is a goal which is central to the Canadian identity and "worth the arduous struggle to attain." ${ }^{\prime 6}$ In a strong and eloquent defense of the judiciary's role under the Charter, Iacobuc ci J., writing for the majority in Vriend on section 1, bemoans the daily griping about judicial intrusions under the Charter and invokes the vision behind the new "social contract" created with the Charter:"

Indeed, it seems that hardly a day goes by

without some comment or criticism to the effect that under the Charter courts are wrongfully usurping the role of the legislatures. I believe this allegation misunderstands what took place and what was intended when our country adopted the Charter in 1981-82.

The Court's decisions in Vriend and Eldridge reach back to the spiritual core of the Andrews decision and to Justice Wilson's view of the role of the judiciary in protecting, in the words of John HartEly, "those groups in society to whose needs and wishes elected officials have no apparent interest in attend ing." 8 Canada's new constitutional democracy, Iacobucci J. notes in Vriend, is based on a concept that is "broader than the notion of majority rule." He cites Dickson C.J. in Oakes: ${ }^{9}$

The Court must be guided by the values and

principles essential to a free and democratic society which I believe to embody, to name but a few, respect for the inherent dignity of the human person, commitment to social justice and equality, accommodation of a wide variety of beliefs, respect for cultural and group identity, and faith in social and political institutions which enhance the participation of individuals and groups in society.

He reaffirms the importance of a rights discourse in ensuring that the needs of marginalized groups are actively engaged in the democratic process. It is the role of the courts to infuse this discourse into Canadian politics by engaging in an ongoing dialogue with governments. ${ }^{10}$

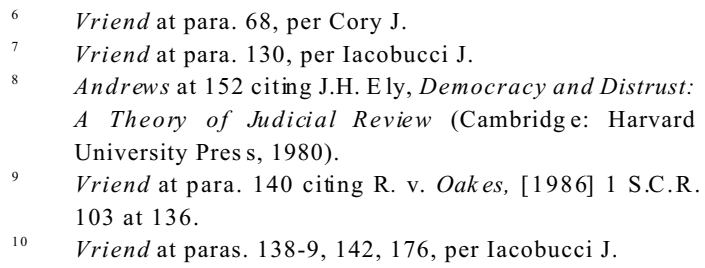

In Eldridge, La Forest, J. writes for a unanimous Court of the history of disabled people in Canada as one which is "largely one of exclusion and marginalization" and of "persistentsocial and econom ic disadvantage," in which "their entrance into the social mainstream has been conditional upon their emulation of able-bod ied norms :"11

For many hearing persons, the dominant

perception of deafness is one of silence. This perception has perpetuated ignorance of the needs of deaf persons and has resulted in a society that is for the most part organized as though everyon e can hear. ${ }^{12}$

In Vriend, Cory J. notes that many will not appreciate the "heavy and disabling burden" on gays and lesbians of being excluded from human rights protections. He cites the U.S. Supreme Court in Romer v. Evans: $:^{13}$

These are protections taken for granted by most people either because they already have them or do not need them; these are protections against exclusion from an almost limitless number of transactions and endeavours that constitute ordinary civic life in a free society.

Giving primacy to the court's role in ensuring that the needs of marginalized groups are not ignored by legislatures relies on a reaffirmation of the positive, remedial component of equality rights. The majority of the Court affirms for the first time in Eldridge and again in Vriend that section 15 guarantees "substantive" as well as "formal" equality. ${ }^{14}$ As frequently as the term has been invoked before the Court by equality seekers, this is the first time the majority of the Court has been prepared to adopt it. In Eldridge, the Court interprets Andrews as holding that section 15 guarantees "a measure of substantive, and not merely formal equality." In Vriend, the unanimous Court in Eldridge is described as affirming "the Charter's requirement of substantive, not merely formal, equality" and recognizing, as well, that "substantive equality may be violated by a legislative om ission." 15 
The question, of course, is what the Court means by "substantive equality." The passage cited from Andrews addresses only the fact thatidenticaltreatment may produce inequality, and differential treatm ent will not always re sult in inequality. Such an approach may ensure that positive measures addressing particular needs arising from disability, pregnancy or systemic discrimination will not be found to be discriminatory, but does not establish the framework for establishing when such positive measures are required. There is a significant further step involved between rejecting a "same treatment" model of equality and accepting that section 15 imposes a positive duty to address needs arising from the distinctive or pressing needs of disadvantaged groups protected by section 15 .

\section{DISCRIMINATORY UNDERINCLUSION: POSITIVE DUtIES CIRCUMSCRIBED BY FORMAL EQUALITY}

The Court has been very solid since Andrews in its rejection of the "same treatment" model of equality. The decision in Weathe rall, ${ }^{16}$ that differential treatment of male and female prisoners with respect to crossgender frisk searches did not violate section 15 , flowed directly from this principle. However, while recognizing in that case that "different treatment may be called for in certain cases to promote equality" the Court stopped short of finding that these measures w ere required by section $15 .^{17}$

The problem in establishing when positive measures are required under section 15 has been that the paradigm of equality analysis laid down in Andrews, while emphasizing that section 15 would have a "large remedialcomponent" and would be interpreted within the broad framework of ameliorating disadvantage, did not provide any framework for identifying when governments are obliged to act to achieve either of these purposes. The trigger for judicial intervention was, in Andrews, a relatively traditional discrimination analysis of distinctions within existing laws. ${ }^{18}$ What remains outside of this "application of the law" is relegated in Andrews to a realm beyond the ambit of section $15:^{19}$

This is not a general guarante of equality; it

does not provide for equality between

\footnotetext{
16 Weatherall v. Canada (Attorney General), [1993] 2 S.C.R. at 872 .

Ibid.

Andrews at 174.

Ibid. at 163-64.
}

individuals or groups within society in a general or abstract sense, nor does it impose on individuals or groups an obligation to accord equal treatment to others. It is concerned with the application of the law.

The broader framework of positive obligations to ameliorate disadvantage existing independently of discriminatory distinctions within applicable laws was thus relegated to the margins in the first decade of the Court's equality analysis. The Court's treatment of the issue of positive obligations has been peripheral and indecisive.

In Schachter, Chief Justice Lamer wrote for the majority that "[i]n some contexts it will be proper to characterize section 15 as providing positiverights." He was critical of the notion of remedying inequality by leveling downwards, or "equality w ith a venge ance," as had been done with social assistance benefits in Nova Scotia when disparities between eligibility of single mothers and single fathers led the Nova Scotia Court of Appeal to strike dow $n$ the bene fits of single mothers. ${ }^{20}$ "While section 15 may not absolutely require that benefits be available to single mothers," w rote Lamer C.J., "surely it at least encourages such action to relieve the disadvantaged position of persons in those circumstan ces." 21

This position was reiterated by the majority in Haig where, dealing with freedom of expression, L'Heureux-Dubé J. distinguished between two types of obligations on government. The first is the requirement that where a government chooses of its own accord to extend a benefit "it may not do so in a discriminatory fashion, and particularly not on ground prohibited under section 15 of the Charter".22

I would add that issues of expression may on occasion be strongly linked to issues of equality. In Schachter v. Canada, [1992] 2 S.C.R. 679, the Court said that section 15 of the Charter is indeed a hybrid of positive and negative protection, and that a government may be required to take positive steps to ensure the equality of people or groups who come within the scope of section 15 . It might well be that, in the context of a particular

$20 \quad$ Phillips v. Nova Scotia (1986), 27 D.L.R. (4th) 156 (N.S.S.C.). See also the related refe rence de cision in Ref. Re Family Benefits Act (Nova Scotia) (1986), 75 N.S.R. (2d) 338 (N.S.C.A.).

21 Schachter v. Canada, [1992] 2 S.C.R. 679 at 702, 721.

22 Haig v. Canada (Chief ElectoralOfficer), [1993] 2 S.C.R. 995 . 
equality claim, those positive steps may involve the provision of means of expression to certain groups or individuals.

As time went by, however, the relatively open-ended comments in Schachter and Haig with respect to the broader ambit of positive obligations were replaced by comments suggesting that the issue of positive obligations had somehow been decided in the negative. In Thibaudeau, L'Heureux-Dubé J. stated that: "Although section 15 of the Charter does not impose upon governments the obligation to take positive actions to remedy the symptoms of systemic inequality, it does require that the government not be the source of further inequality." ${ }^{23}$ Then in Egan, Lamer C.J., writing for the majority, stated that:

It is clear that Parliament does not have any

constitutional obligation to provide benefits.

However, once the decision has been made to confer a benefit, it cannot be applied in a discriminatory manner. See Brooks v. Canada Safeway Ltd., [1989] 1 S.C.R. 1219 at 1240; Schachter v. Canada, [1992] 2 S.C.R. 679 at 721-22.

All of these statements, of course, were obiter dicta. In none of the cases did any of the parties ask the Court to find that the government had failed to comply with a positive duty to address needs arising from disadvantaged status in society. Nevertheless, a consensus seemed to be emerging on the Court that positive measures beyond those required to remedy discriminatory underinclusion were beyond the ambit of section 15. The legacy of Andrews, Brooks and Schachter seemed to be that, rather than opening the door to an understanding of the profound positive dimensions of the right to equality and government obligations to ameliorate disadvantage as Helena Orten had hoped, these early cases were taken as circumscribing the limits of positive duties within the confines of what was essentially a formal equality model, devoid of any commitment to positive obligations at the core of substantive protections of rights.

Under the approach suggested by Lamer C.J. in Egan, the government is under no obligation to provide maternity benefits or parental benefits in order to ensu re meaningful equality for w omen in the workp lace. The only obligation is to ensure that once provided, such benefit schemes do not discriminate. The government similarly would be under no obligation to protect disadvantaged groups from discrimination through human rights legislation or to provide medical services to people who are sick. The whole scheme of the equality protections had come to spin around a missing axis. There were positive obligations to remedy discriminatory exclusion from benefits or legislation, but not to remedy the more substantive violations of rights existing independently of a statutory distinction.

On the face of it, what we have won explicitly from the Court in Eldridge and Vriend with respect to positive obligations is merely a retreat from the position taken in Egan which suggests that the issue of positive obligations has been decided in the negative. The issue has now been decisively placed in the "undecided" category. In Eldridge, La Forest J. states that: ${ }^{24}$

It has been suggested that section 15(1) of the

Charter does not oblige the state to take positive actions, such as provide services to ameliorate the symptoms of systemic or general inequality; see Thibaudeau, supra at para. 37 (per L'Heureux-Dubé J.). Whether or not this is true in all cases, and I do not purport to decide the matter here, the question raised in the present case is of a wholly different order.

In Vriend, the majority of the Court goes a little further in suggesting that there would be a basis for finding a positive obligation to legislate or to act in some circumstances, but still leaves the matter form ally undecided. ${ }^{25}$

It is also unnecessary to consider whether a government could properly be subjected to a challenge under section 15 of the Charter for failing to act at all, in contrast to a case such as this where it acted in an underinclusive manner. It has been held that certain provisions of the Charter, for example those dealing with minority language rights (section 23), do indeed require a government to take positive actions to ensure that those rights are respected (see Mahé v. Alberta, [1990] 1 S.C.R. 342 at 393; Reference re Public Schools Act (Man.), s. 79(3), (4) and (7), [1993] 1 S.C.R. 839 at 862-63, 866).
$23 \quad$ Thibaudeau v. Canada (1995), 124 D.L.R. (4th) 449 at 466 (S.C.C.) per L'Heureux -Dubé J.
Eldridge at 621.

Vriend at paras. 63-64. 
It has not yet been necessary to decide in other contexts whether the Charter might impose positive obligations on the legislatures or on Parliament such that a failure to legislate could be challenged under the Charter. Nonetheless, the possibility has been considered and left open in some cases. For example, in McKinney, Wilson J. made a comment in obiter that "[i]t is not self-evident to me that government could not be found to be in breach of the Charter for failing to act" (p. 412). In Haig v. Canada, [1993] 2 S.C.R. 995 at 1038, L'H eureux-D ubé J., speaking for the majority and relying on comments made by Dickson C.J. in Reference re Public Service Employee Relations Act (Alta.), [1987] 1 S.C.R. 313, suggested that in some situations, the Charter might impose affirmative duties on the government to take positive action. Finally, in Eldridge v. British Colum bia (Attorney General), [1997] 3 S.C.R. 624, La Forest J., speaking for the Court, left open the question whether the Charter might oblige the state to take positive actions (at para. 73). However, it is neither necessary nor appropriate to consider that broad issue in this case.

In both Eldridge and Vriend the appellants and their supporting intervenors framed their section 15 claim within the formal equality paradigm of discrimination - through under inclusion. They argued that their claims did not require the Court to consider whether governments have a positive obligation to provide benefits or to legislate. The issue as they defined it was whether a legislative omission or underinclusion resulted in discrimination within the scheme for the provision of benefits or legislative protections. It is significant, however, that in both cases, the Court went well beyond the type of analysis proposed by the appellants to adopt a more substantive equality model incorporating positive obligations.

When one examines more closely what the Court actually decided in these two cases and how decisively it broke with the premises of the earlier paradigm of formal underinclusion, one has to conclude that, in fact, the Court is resisting the implications of its own analysis. The Court has effected, in these cases, a profound change in the approach to the analysis of the "application of the law" under section 15 which has prevailed since Andrews. While both decisions attempt to remain within the earlier paradigm of underinclusion, they systematically remove all of the premises on which it is based.

\section{ELDRIDGE: The DUty to Provide}

Preceding La Forest J.'s two sentence "abstention" on the question of positive obligations in Eldridge, which almost seems "pasted in," is an unequivocal rejection of any approach which would limit section 15 to challenging discrimination within existing programs and not oblige governments to implement programs to ameliorate disadvantage $:^{26}$

In their effort to persuade this Court

otherwise, the respondents and their supporting interveners maintain thatsection 15(1) does not oblige governments to implement programs to alleviate disadvantages that exist independ ently of state action. Adverse effects only arise from be nefit programs, they aver, when those programs exacerbate the disparities between the group claiming a section 15(1) violation and the general population. They assert, in other words, that gove rnments should be entitled to provide benefits to the general population without ensuring that disadvantaged members of society have the resources to take full advantages of those benefits.

In my view, this position be speaks a th in and impoverished vision of section 15(1). It is belied, more importantly, by the thrust of this Court's equality jurisprudence.

Justice La Forest proceeds to review section 15 and human rights jurisprud ence to show that, particu larly in adverse effects analy sis under human rights legislation, it has been recognized that discrimination can accrue from a failure to take positive steps to ensure equal access to services. In this context he cites the majority of the Court in Haig that "a government may be required to take positive steps to ensure the equality of people or groups who come within the scope of section $15 ., 27$

Justice La Forest attempts to put to rest the almost universal misapplication by lower courts of Iacobucci J.'s remarks in Symes, where he cautioned that we must "distinguish between effects which are wholly caused, or are contributed to, by an impugned provision, and those social circumstan ces whic h exist independ ently of

Eldridge at 621.

Ibid. at 623 citing Haig v. Canada (Chief Electoral Officer), [1993] 2 S.C.R. 995 at 1041 
such a provision." 28 These remarks, La Forest J. notes, were made in the context of a concern that, in Symes, unless it was established that women disproportio nately bear the cost of childcare, the Court could not find the necessary connection between the impugned provision and the social disadvantage of women. ${ }^{29}$ In other words, the Court nee ded evide nce that, if it were to grant the remedy sought, the disadvantage at issue would in fact be ameliorated. This would not be the case, according to the Court, if businessmen were equally able to claim the tax deduction. The "causation" requirement set out in Symes, however, does not in any way prevent section 15 from being applied so as to require governments to take positive measures to address issues of social inequality which are not caused by the application of existing law.

In Eldridge, the constitutional question as framed by the appellants was whether the definition of "benefits" in section 1 of the Medicare Protection Act $\mathrm{A}^{30}$ violated section 15 by failing to include medical interpreter services for the deaf, and whether the Hospital Insurance $A c t^{31}$ and Regulations enacted pursuant to section 9 of that $A c t$ violated section 15 by failing to require that hospitals provide medical interpreter services for the deaf. The failure to provide a service was thus tied to a distinction within existing statutory provisions. Framing the failure to provide a necessary service as an issue of statutory underinclusion, however, distorted the issue somewhat. In order to establish the connection with the "application of law" a kind of mythical "legislative act" or "decision of elected legislators" was created which, in fact, exaggerated the case for judicial deference to the legislature. The discrimination at issue in Eldridge was not really tied in any direct way to an act of the Legislature or even to decisions of elected representatives not to act. It was framed by the appellants as a statutory "underinclusion" primarily because that is how section 15 claims had always been approach ed by the Court.

While the failure to provide interpreter services could certainly be remedied by reading the requirements sought by the appellants into the Medicare Protection Act and the Hospital Insurance $A c t$, it is doubtful that such a remedy was the most appropriate way to solve the problem. The problem was not that interpreter services were not billed on a fee-for-

28 Ibid. at 622 citing Symes v. Canada, [1993] 4 S.C.R. 695 at 764-65.

Ibid. at 622 .

S.B.C. 1992 , c.76.

R.S.B.C. 1979 , c. 180 . service basis as a medical service or that the Hospital Insurance Act failed to require the provision of such services. It was that those who had the authority and the means to ensure that such services were provided officials within the Health Ministry and the hospital administration - simply ignored the needs of a marginalize d group.

The story leading up to Robin Eldridge's inab ility to communicate effectively with her physician and to John and Linda Warren's frightening experiences during the birth of their tw ins when they could not fully understand what their doctors and nursing staff were trying to communicate to them was not the story of a discriminatory distinction in law created by the elected legislators. It was, as Justice Wilson imagined it in Andrews, a familiar story of government officials showing little understanding of, or inclination to attend to the needs of, a disadvantaged minority. The issue never reached the floor of the legislature.

Interpreter services for the deaf in the lower mainland of British Columbia w ere provided until 1990 without any government funding by the Western Institute for the Deaf and Hard of Hearing, a private, non-profit agency. In 1989 the agency began experiencing serious financial difficulties. Funding was sought through officials at the Ministry of Health but was turned down initially because the request came midway through a fiscal year. In 1990 the agency w rote to the Assistant Deputy Minister, Community and Family Health, notifying him that they could no longer provide inte rpreter services.

A briefing note was prepared for the Executive Committee at the Ministry of Health by the Executive Director of the Family Health Division. He noted that the Institute had requested that interpreter services be covered as an insured benefit under the Medical Services Plan but, "on examination, this is more to highlight their point that this is a legitimate part of the health care process rather than seeing it as an ideal mechanism for the delivery of the service." 32 The briefing note recommended funding as a grant/contract rather than as a fee-for-service. ${ }^{33}$ The Executive Committee discussed the request for less than twenty minutes and turned it down. ${ }^{34}$

The discrimination at issue in Eldridge, then, directly arose from a program ceasing to exist and a

32 Eldridge at 588; Appellants' Factum, paras. 49-50, COA Exhibit 3, pp.306-308.

33 COA Exhibit 3 Tab 1.

34 Ibid. 
decision by unelected officials within government not to provide funding either for the existing program or a new one in order to m aintain the interp reter services.

Considering this typical example of a failure to provide for a need of a disadvantaged group under section 15, the Court in Eldridge properly tried to focus on the actual sou rce of the disc rimination - a failure to provide for a need - rather than on legislative underinclusion. The Court found no violation of section 15 in either of the impugned statutes and answered "No" to the constitutional questions put by the appellants. It found, instead, that the Medical Health Care Services Act delegates the power to determine what "medically required services" are to be considered "benefits" under the Act to the Medical Services Commission. It was the decision of the Commission not to include interpreter services as a required service, rather than the legislation, which according to the Court was con stitutionally sus pect. ${ }^{35}$

Similarly, the Hospital Insurance Act leaves hospitals with considerable discretion to decide how to allocate a global grant for general hospital services and how to provide their services. Nothing in the legislation precludes them from supplying sign language interpreters. While hospitals are not subject to the Charter in other respects, as the Court had found in Stoffman, ${ }^{36}$ here they are acting as the vehicle for the delivery of "a comprehensive social program" and as such are subject to applic ation of the Charter.

The Court thus focused on the failure to provide for a particular need and dispensed with the unnecessary complexities of the Andrews analysis of a distinction in law. In this type of "failu re to provide" discrimination, the comparison is not between those who are provided a benefit and those who are denied it, as in the traditional paradigm of underinclusion. Rather it is between those who need a benefit in order to enjoy equality and those who do not. The failure to provide interpreter services has an adverse effect on those who require such services in order to have effective communication within the healthcare system. It denies deaf people the equal benefit of the law and "discriminates against them in comparison with hearing persons.", 37

Any failure to provide for a need may properly be subject to section 15 , then, where the failure to provide

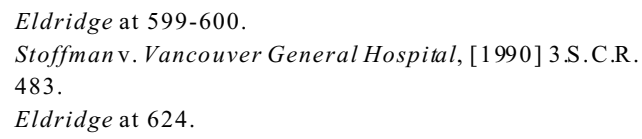

creates an inequality between a disadvantaged group protected by section 15 and those who are not disadvantaged - betw een those who need the benefit or program and those who do not. In other words, it would no longer be correct to state that the government has no obligation to provide matemity benefits but once provided, must do so without discriminating. The approach adopted by the unanimous Court in Eldridge suggests that a failure to provide for the needs of pregnant women would infringe section 15 because failing to provide for such a need would discriminate against women, who need the be nefit, in comparison to men, who do not.

The resulting inequality at issue in Eldridge, of course, is within the healthcare system - a public service for which the government is responsible. To the extent that the Court is able to hang on to its traditional paradigm of underinclusion, it is by emphasizing the obligation on governments to provide such services in a manner which ensures that disadvantaged groups "have the resources to take full advantage of those benefits." 38 The question of necessary resources, however, is not one which involves analysis of the law so much as the complexities of a government's interaction with various needs and claims upon its resources. The violation of section 15 at issue in Eldridge did not arise when any particular legislation was passed and proclaimed or any particular decision made pursuant to the legislation. It was at the point when the need arose and government or its delegates failed to respond that a violation of section 15 occurred.

In order to remain on more familiar section 15 terrain, the Court in Eldridge ties the section 15 violation to the exercise of discretion accorded by statute. It finds that both the Hospital Services Commission under the Medical and Health Care Services Act and the Hospitals under the Hospital Insurance Act had the statutory discretion to provide funding for interpreter services when the need arose. Yet in its section 1 analysis, the Court focuses on the decision of the Executive Committee of the Ministry of Health not to allocate $\$ 150,000$ of its budget to allow the Western Institute for the Deaf and Hard of Hearing to provide a province-wide service. ${ }^{39}$

Decisions not to provide, or failures to act in the face of the need of vulnerable groups, can rarely be pinpointed to one actor within government or to a particular statute. Under the emerging framew ork in Eldridge, the violation occurs, essentially, with the

$38 \quad$ Ibid. at 621

$39 \quad$ Ibid. at 628 . 
unmet need, not with any particular statute or decision pursuant to a statute. The Court in Eldridge recognizes, when it comes to remedy, that there are "myriad options available to the government that may rectify the unconstitutionality of the current system." The government is simply given the constitutional responsibility to: ${ }^{40}$

ensure that sign lang uage interp reters will be

provided where necessary for effective communication in the delivery of medical services. Moreover, it is presumed that the government will act in good faith by considering not only the role of hospitals in the delivery of medical services but also the involvement of the Medical Services Commission and the Ministry of Health.

Thus, in Eldridge we see emerging a new approach to substantive equality. The Court ultimately decided that there was a governmental responsibility to address the need for interpreter services in whatever manner it found most appropriate and that the government had failed to live up to that responsibility. The Court appropriately departed from the "read-in" remedy utilized for underinclusive legislation and simply ordered the government to meet its positive obligations under section 15 by ensuring that the needs of the deaf within the health care delivery system are properly addressed. That responsibility could be met through the creation of a new program, through funding of a nonprofit agency to provide the services, through the inclusion of interpreter services as medical services or by any other appropriate means. In response to the Court's decision, the Executive Committee has in fact directed that a new program be established. The Ministry has consulted extensively with the Deaf, Deaf/Blind and Hard of Hearing communities - the groups which pre viously had no voice in the decisionmaking process. ${ }^{41}$

It makes no sense to recognize that a violation of section 15 may be created by the elimination of a program and remedied by the creation of a new program without at the same time admitting that a failure to provide a program or benefit may constitute a violation of section 15 . The point of the purposive approach emerging from Eldridge is to focus on the inequality which needs to be remedied by the provision of a service or benefit rather than on the question of

\footnotetext{
Ibid. at 631-32

Eldridge, Applic ation for a Stay of the Decision of the S.C.C. of the 9th of October, 1997, Court File No. 24896. Affidav it of Heather Davidson, sworn the 25 th day of March, 1998.
}

how the inequality is connected to an existing statute. Once it is accepted that a government has a responsibility to meet certain needs of disadvantaged groups, which the Court accepts in Eldridge, then the failure to meet these needs constitutes a violation of section 15 at the moment the need arises and is ignored. There is really no requirement of an "application of law" beyond the requirement that it be within the government's jurisdiction to address the need.

\section{VRIEND: THE DUTY TO LEGISLATE PROTECTIONS}

In Vriend, of course, the issue is a failure to legislate rather than to provide funding for a service. The connection to "law" is much more explicit than in Eldridge. Here, as in Eldridge, the equality claim was framed by the appellants and by most of their supporting intervenors, $w$ ithin the traditional paradigm of underinclusion. No one argued that the obligation to protect gays and lesbians from discrimination because of sexual orien tation should be approached within the context of a broade r obligation to le gislate hum an rights protections for vulnerable groups. Rather, they argued that once the legislature provides the benefit of human rights protections to some groups, it cannot discrim inate against gays and lesbians by denying them the same protection from analogous discrimination. The appellants thus took the position that there was no need to decide the broader issue of a positive obligation to legislate human rights protections.

As Diane Pothier has pointed out, this traditional underinclusion paradigm relies on a comparison between disadvantaged groups ("between grounds") rather than on the more important comparison between a disadvantaged group and an advantaged group ("within grounds"). ${ }^{42}$ Gays and lesbians are entitled to protection under the formal underinclusion analysis only because women and racial minorities and other disadvantaged groups have them. The traditional paradigm thus forces an issue of substantive equality into a somewhat distorted form, directed away from the fundamental inequality that is really at issue in the case.

In Vriend, the Court accepts that the comparison with other disadvantaged groups protected under the Act justifies a finding of "for mal" inequality or underinclusion. However, it finds that the more important distinction is that which derives from the substantive

$42 \quad$ D. Pothier, "The Sound s of Silen ce: Charter Application When the Legislature Declines to Speak" (1996) 7 Constitutional Forum 113 at 119. 
model of equality developed in Eldridge, between those who need the protection and those who do not: ${ }^{43}$

The second distinction, and, I think, the more

fundamental one, is between homosexuals and heterosexuals. This distinction may be more difficult to see because there is, on the surface, a measure of formal equality: gay or lesbian individuals have the same access as heterosexual individuals to the protection of the IRPA in the sense that they could com plain to the Commission about an incident of discrimination on the basis of any of the grounds currently included. However, the exclusion of the ground of sexual orientation, considered in the context of the social reality of discrimination against gays and lesbians, clearly has a disproportionate impact on them as opposed to heterosexuals. Therefore the $I R P A$ in its underinclusive state denies substantive equality to the former group.

Moreover, in Vriend the Court makes explicit what is implicit in Eldridge, that government need not have entered a particular legislative or benefit area in order for a Charter claim to be made with respect to a failure to act to address a need: ${ }^{44}$

The relevant subsection, section $32(1)(b)$,

states that the Charter applies to "the legislature and government of each province in respect of all matters within the au thority of the legislature of each province." There is nothing in that wording to suggest that a positive act encroaching on rights is required; rather the subsection speaks only of matters within the authority of the legislature. Dianne Pothier has correctly observed that section 32 is "worded broadly enough to cover positive obligations on a legislature such that the Charter will be engaged even if the legislature refuses to exercise its authority" ("The Sounds of Silence: Charter Application When the Legislature Declines to Speak" (1996), 7 Constitutional Forum 113 at 115).

Whereas the positive equality obligations affirmed in Eldridge could con ceivably be circumsc ribed within the requirement that governments be nondiscriminatory in the provision of government services, the majority in Vriend makes it clear that section 15 creates broader obligations to protect and promote equality in all areas where the government has the jurisdiction to act. In response to the respondent's arguments that the inequality at issue in Vriend is not within government legislation or services but within the private arena, the Court answ ers simply that "[e]ven if the discrimination is experien ced at the hands of priva te individuals, it is the state that denies protection from that discrimination." ${ }^{, 45}$ Legislative inaction or silence should not be assumed to be neutral. It is only by analysing its effects, whe ther in the public or private sphere, that the courts will determine whether such inaction is consistent with the Charter's guarantee of equal benefit and protection of the law. ${ }^{46}$

In the context of so clear and unambiguous an affirmation of positive obligations under section 15 , it is difficult to understand the logic of the Court's abstention with respect to the positive obligation to legislate in the human rights field. Clearly the obligation to have human rights legislation flows directly from the substantive equality analysis taken over from Eldridge. If the obligation to protect gays and lesbians derives from the discriminatory effect of failing to provide protection to a group which faces widespread discrimination, surely that obligation applies equally to all groups needing protection from discrimination. While a finding of a violation of formal equality could perhaps be remedied by revoking human rights legislation entirely, such an unthinkable measure would clearly violate the guarantee of substantive equality. Not only would gays and lesbians be disproportionately impacted by an ab sence of human rights legislation, so would Blacks and people of colour, Jews, people with disabilities, welfare recipients, women, youth, religious minorities and every other group which needs human rights protections. The Court's affirmation of a substantive equality analysis rather than a formal equality analysis based on underinclusion makes human rights legislation, appropriately, a constitutiona 1 requirement.

\section{THE INTERNATIONAL HUMAN RIGHTS MOdEL: POSITIVE OBLIGATIONS AT THE CORE OF SUBSTANTIVE RIgHTS}

The Court's obvious reluctance to take the step of recognizing positive obligations to legislate under the Charter is puzzling in light of its recognition in other cases of the importance of intern ational hum an rights which "reflect the values and principles that underlie
$43 \quad$ Vriend at paras. 81-82, per Cory J.

${ }^{44} \quad$ Ibid. at para. 60.
45 Ibid. at para. 103, per Iacobucci J.

$46 \quad$ Ibid. at para. 57, per Cory J. 
the Charter itself." ${ }^{47}$ Within international human rights jurisprudence, the idea of trying to understand fundamental human rights in the absence of positive obligations to legislate or to provide for the needs of disadvantaged groups is simply unthinkable. The Universal Declaration of Human Rights ${ }^{48}$ and subsequent human rights instruments are most fundamentally an expression of a resolve by governments to protect, through legislation and other positive measures, vulnerable groups in society from violations of their human rights. Canada has bound itself to obligations in international human rights to legislate protections for vulnerable groups and to provide, to the maximum of available resources, what is necessary to guarantee their fundamental human rights. Our strong commitment to the rule of international human rights law would seem to be a fundamental component of the distinctive Canadian identity affirmed by Cory $\mathrm{J}$. for the majority in Vriend.

Chief Justice Dickson, writing for the majority of the Court in Slaight Communications, cited his earlier words in Reference Re Public Service Relations Act (Alta) that: ${ }^{49}$

The content of Canada's international human rights obligations is, in my view, an important indicia of the meaning of the 'full benefit of the Charter's protection.' I believe that the Charter should generally be presumed to provide protection at least as great as that afforded by similar provisions in international human rights documents which Canada ratified.

Applying this basic interpretive approach to the issues before the Court in Eldridge and Vriend would suggest that a basic starting point of any analysis should be an assumption of positive obligations to provide for needs and legislate necessary protections. With respect to disabilities, the obligation on governments in Canada under international law is to take positive action: $:^{50}$

The obligation of States parties to the

Covenant to promote progressive realization of the relevant rights to the maximum of their available resources clearly requires Governents to do much more than merely abstain

47 Slaight Communications Inc. v. Davidson, [1989] 1 S.C.R. 1038 at $1056-57$.

48 Universal Declaration of H uman Rights, GA Res. 217A (III), U.N. Doc. A/810 (1948).

$49 \quad$ Supra note 47 at 1056.

50 U.N. Committee on Economic, Social and Cultural Rights, General Comm ent No. 5, 11th S ess., 38 th Mtg., U.N. Doc. E/C.12/1994/13 (1994) para.9. from taking measures which might have a negative impact on persons with disabilities. The obligation in the case of su ch a vulne rable and disadvantaged group is to take positive action to reduce structural disad-vantages and to give appropriate preferen tial treatment to people with disabilities in order to achieve the objectives of full participation and equality within society for all persons with disabilities. This almost invariably means that additional resources will need to be made available for this purpose and that a wide range of spe cially tailored measures will be required.

Similarly, with regard to the right to equality and non-discrimination at issue in Vriend, the International Covenant on Civil and Political Rights establishes that "where not provided for by existing legislative or other measures" governments are obliged to "to adopt such legislative or other measures as $m$ ay be necessary to give effect to the rights ..." 51 The Human Rights Committee has made it clear that governments are obliged to legislate protections from discrimination in both the private and public spheres. ${ }^{52}$

In Eldridge, the Court's formal abstention on the question of broader positive obligations emanating from section 15 was inconsistent with its analysis of substantive equality, but unders tandable given the fact that the issue did not directly arise in the case. In Vriend, however, the Court's refusal to decide the question of whether there is an overriding obligation to legislate human rights protections has remedial consequences which are simply unacceptable in the type of constitutional democracy affirmed by the majority of the Court.

In his discussion of remedy in Vriend, Major $\mathrm{J}$. draws out the implications of the majority's abstention on the question of the obligation to legislate: ${ }^{.3}$

The issue may be that the Legislature would

prefer no human rights Act over one that includes sexual orientation as a prohibited ground of discrimination, or the issue may be how the legislation ought to be amended to bring it into conformity with the Charter. That

51 International Covenant on Civil and Political Rights, Can. T.S. 1976 No. 47 (concluded December 16, 1966; in force for Canada August 19, 1976). Articles 2 and 26.

52 U.N. Human Rights Committee, Concluding Observations on the Report of the United Kingdom relating to Hong Kong (adopted November 1996) reprinted in (1996) Human Rights Law Journal Vol. 17, No. 11-12.

$53 \quad$ Vriend at para. 196, per Major J. 
determination is best left to the Legislature.

Consider our predicament. A Justice of the Supreme Court of Canada, guardian of the sacred constitutional rights of which, according to the majority, we are to be so proud, is inviting the legislature of a province to make Canada into an outcast of the world human righ ts community by revoking allhuman rights protections for vulnerable groups. As a remedy to a finding of unconstitutionality, it is suggested that the Province of Alberta could place Canada in clear violation of virtually every international human rights treaty we have ratified. In what the majority calls a "dialogue" between the courts and the legislatures designed to enhance the democratic process, ${ }^{54}$ the legislature is informed that it could remedy a violation of the equality rights of one group by removing them from all licensing invidious racism, anti-semitism, homophobia, racial and sexual harassment of all kinds, any kind of discrimination against people with mental or physical disabilities and the denial of jobs and housing an d basic services to the most vulnerable groups in society.

Rather than following the logic of its affirmation of substantive equality and positive obligations, and stating that such an unthinkable remedy would constitute an egregious violation of section 15 , the majority in Vriend distinguishes itself from Major J. merely on the basis of assumptions as to legislative preference: ${ }^{55}$

It is reasonable to assume that, if the

legislature had been faced with the choice of having no human rights statute or having one that offered protection on the ground of sexual orientation, the latter option would have been chosen.

\section{Conclusion}

We recall from the late Thomas Kuhn that as

scientific paradigms begin to break down and make way for new ones, the anomalies that were previously swept to the side become increasingly disturbing and threatening to the viability of the whole approach. ${ }^{56}$ The same is apparently true of legal paradigm shifts. The inconsistencies that become particularly disturbing in Vriend arise only to the extent that the Court insists on clinging to a familiar parad igm of form al equality w hile at the same time moving beyond it. The Court says it is

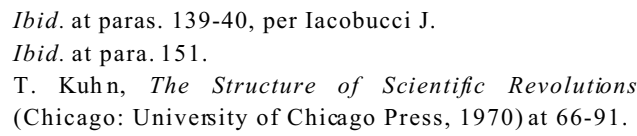

not deciding the issue of the obligation to legislate when in fact the determination of that issue is the very core of its new approach to substantive equality.

The peculiar Canadian resistance to the notion that the Charter imposes positive obligations on governm ents to provide legislative and social protection for disadvantaged groups - so central to international human rights norms - is not confined to the Supreme Court. Our political and legal culture, as has been so sadly evident in some of the public and political response to the Court's decision in Vriend, is imbued with what ranges from ske pticism to ou tright hostility toward the idea of courts ordering governments to legislate or provide benefits. This tendency, which runs across the political spectrum, has seriously skewed our approach to human rights in Canada, particularly as the issues of substantive inequality loom larger.

In the thirteen years since section 15 came in to effect we have witnessed alarming inc reases in hunger, homelessness, poverty and exclusion among many of the groups protected by section 15. Increasingly, governments have withdrawn from programmatic and legislative commitments to remedying substantive inequality. International human rights bodies have voiced increasing concern over these developments, urging the courts and human rights commissions to be more rigorous in applying the Charter and human rights legislation to substantive human rights violations in Canada. ${ }^{57}$ Their concerns and recommendations have been ignored. Equality claims advanced by the poorest members of society have been almost universally rejected by lower courts, with governments arguing for the narrowest possible reading of equality rights, completely at odds with commitments in international law. ${ }^{58}$

57 See for example, Committee on Economic, Social and Cultural Rights: Concluding Observations on Report of Canada Concerning the Rights Covered by Articles 10 to 15 of the InternationalCovenant on Economic, Socialand Cultural Rights UN doc. E/C.12/1993/19; 20 CHRR C/1. 58 See for ex ample, Gosse lin v. Québec (Proc ureur Général) [1992] R.J.Q. 1647 (Que. S.C.); Re: Fernandes and Director of Social Services (Winipe g Cen tral) (1992), 93 D.L.R. ( $\left.4^{\text {th }}\right) 402$ (M an. C.A.); Masse v. Ontario (Com. Soc. Services) (1996), 134 D.L.R. (4 $\left.{ }^{\text {th }}\right) 20$ (Div. Ct.); Clark v. Peterborough Utilities Commission (1995), 24 O.R. (3d) 7 (Gen. Div.). See also M. Jackman, "Poor Rights: Using the Charter to Support Social Welfare Claims" (1993) 19 Queen's Law Journal 65; Bruce Po rter, "The Uninvited Guests: Reflections on the Brief History of Poor People Seeking their Rightful Place in Equality Jurisprudence" in Roads to Equality Vol. 3, (Canadian Bar Association, Continuing Legal Education Program, Annual General Meeting, 1994); S. Day and G. Brodsky, Women and the equality deficit: the impact of 
In Eldridge and Vriend the Court has provided us with the legal tools to challenge the most important inequalities in society arising from government acquiescence in the face of violations of fundamental human rights. In retreating from an explicit statement affirming positive obligations to legislate and provide benefits, however, and reminding us that Parliament and the legislatures have the final say in Canada through the "notwithstanding clause," the Court may also be sending a message that it's role is limited. It is only one voice in the rights "dialogue." Substantive rights must become part of public as well as legal discourse. If a new paradigm of substantive rights is to prevail, it will require changes in many areas, not just in equality jurisprudence and not just in the Court. Human rights commissions, government officials, legal practitioners, politicians and the media must be convinced to approach the question of rights in a new way, more integrated with the norms of inclusive democracy, international human rights norms and fundamental social justice. In Vriend and Eldridge the Court has taken an important initiative toward framing a new paradigm of substantive equality. There is a lot of work to be done to fill it in and give it effect. $\square$

\section{Bruce Porter}

Director, Centre for Equality Rights in Accommodation (CERA). 